\title{
PENGARUH MODAL KERJA DAN PERPUTARAN KAS TERHADAP TINGKAT LIKUIDITAS PADA PERUSAHAAN TEKSTIL DI BEI
}

\author{
Meutia Dewi \\ Fakultas Ekonomi, Program Studi Manajamen, Universitas Samudra \\ e-mail: meutiadewi@unsam.ac.id
}

\begin{abstract}
Abstrak
Penelitian ini dilakukan bertujuan untuk mengetahui pengaruh modal kerja dan perputaran kas terhadap tingkat likuiditas (rasio lancar) pada perusahaan tekstil yang terdaftar di Bursa Efek Indonesia. Metode analisis data yang digunakan terdiri dari persamaan regresi linier berganda, uji koefisien determinasi $\left(\mathrm{R}^{2}\right)$, uji hipotesis terdiri dari uji t dan uji $\mathrm{F}$. Hasil penelitian diperoleh untuk persamaan $\mathrm{Y}=511,159-61,824 \mathrm{X}_{1}-0,002 \mathrm{X}_{2}$, konstanta menunjukkan bahwa tingkat likuiditas sebesar 511,159 sebelum dipengaruhi oleh modal kerja dan perputaran kas. Kemudian koefisien regresi modal kerja dan perputaran kas memberikan pengaruh negatif terhadap tingkat likuiditas pada perusahaan tekstil yang terdaftar di BEI. Hasil uji koefisien determinasi diperoleh sebesar 0,182 atau $18,2 \%$ variabel modal kerja dan perputaran kas mempengaruhi tingkat likuiditas (rasio lancar) pada perusahaan tekstil yang terdaftar di Bursa Efek Indonesia. Hasil uji t modal kerja kerja dan perputaran kas diperoleh nilai $t$ sig $<\alpha 5 \%$ sehingga dapat dinyatakan bahwa modal kerja dan perputaran kas berpengaruh signifikan terhadap tingkat likuiditas (rasio lancar) pada perusahaan tekstil pada perusahaan Bursa Efek Indonesia. Hasil uji F diperoleh F sig 0,011< $<5 \%$ sehingga dapat dinyatakan bahwa secara simultan modal kerja dan perputaran kas memberikan pengaruh signifikan terhadap likuiditas (rasio lancar) pada perusahaan tekstil pada perusahaan Bursa Efek Indonesia.
\end{abstract}

Kata kunci: Modal Kerja, Perputaran Kas, Likuiditas, Rasio Lancar 
Perkembangan ekonomi saat ini sangat pesat sehingga permasalahan yang dihadapi oleh bidang usaha semakin kompleks dan bersifat dinamis. Salah satu masalah yang selalu dihadapi oleh perusahaan adalah masalah keuangan. Pengelolaan di bidang keuangan baik dalam jangka panjang maupun jangka pendek selalu berkaitan dengan kegiatan perusahaan sehari-hari termasuk didalamnya pengelolaan modal kerja dan aktiva yang baik karena akan berpengaruh terhadap likuiditas perusahaan. Pengelolaan dan penggunaan modal kerja yang efisien merupakan salah satu faktor yang dapat menunjang pencapaian laba bersih secara optimal

Modal kerja merupakan salah satu aspek terpenting dari keseluruhan manajemen pembelanjaan perusahaan. Apabila perusahaan tidak dapat mempertahankan "tingkat modal kerja yang memuaskan”, maka kemungkinan perusahaan tidak mampu membayar kewajiban-kewajiban yang sudah jatuh tempo dan bahkan mungkin dilikuidasi. Aktiva lancar yang cukup besar untuk menutup hutang sedemikian rupa, sehingga menggambarkan adanya tingkat keamanan yang memuaskan.

Selain modal kerja yang dilihat dari jumlah aktiva lancar pada perusahaan dapat juga dilihat jumlah kas yang tersedia. Jika modal kerja menyangkut seluruh aktiva lancar seperti kas, piutang, persediaan, perlengkapan dan pembayaran dimuka, maka kas adalah harta yang lebih likuid dari unsur modal kerja lainnya. Kas dapat digunakan langsung untuk setiap operasional perusahaan dan diharapkan memiliki perputaran yang cepat, yaitu jika di gunakan untuk setiap kegiatan perusahaan dapat kembali ke kas sesegera mungkin.

Perusahaan dalam menjalankan kegiatan usahanya tidak terlepas dari tujuannya yaitu untuk memperoleh laba yang maksimal dan kelangsungan hidup (going concern). Kelangsungan hidup perusahaan dipengaruhi oleh banyak hal antara lain likuiditas perusahaan itu sendiri. Menurut Wild et al. (2005:185) "Likuiditas (liqudity) mengacu pada kemampuan perusahaan untuk memenuhi kewajiban jangka pendeknya". Pentingnya likuiditas dapat dilihat dengan mempertimbangkan dampak yang berasal dari ketidakmampuan perusahaan memenuhi kewajiban jangka pendeknya. Kurangnya likuiditas menghalangi perusahaan untuk memperoleh keuntungan dari diskon atas kesempatan mendapatkan keuntungan. Pernyataan tersebut diperkuat oleh Riyanto (2010:26) tentang pendefinisian likuiditas yang berarti kemampuan perusahaan untuk menyediakan alat-alat likuid sedemikian rupa sehingga dapat memenuhi kewajiban finansialnya pada saat ditagih, apabila kemampuan membayar tersebut dihubungkan dengan kewajiban finansial untuk menyelenggarakan proses produk maka dinamakan "Likuiditas Perusahaan".

Terdapat banyak ukuran yang dipakai untuk melihat kondisi likuiditas suatu perusahaan, antara lain dengan menggunakan rasio lancar. Rasio ini menunjukkan sejauh mana aktiva lancar menutupi kewajibankewajiban lancar yang dimiliki perusahaan tersebut, semakin besar perbandingan aktiva lancar dengan kewajiban lancar maka semakin tinggi kemampuan perusahaan menutupi kewajiban jangka pendeknya.

Perusahaan Tekstil sebagai objek penelitian ini dikarenakan perusahaan ini merupakan salah satu perusahaan yang memegang peranan penting dalam masyarakat. Krisis ekonomi yang melanda Indonesia serta kenaikan bahan baku dan kenaikan Bahan Bakar Minyak tentunya sangat berpengaruh terhadap perusahaan industri tekstil. Walaupun demikian perusahaan tekstil yang ada di Indonesia selalu dapat beroperasi dengan baik. Hal tersebut diketahui dari perusahaan-perusahaan tekstil yang terdaftar di Bursa Efek Indonesia sampai saat ini masih tetap eksis yang terdiri dari 18 perusahaan. Perusahaan-perusahaan tersebut yaitu, PT. Roda Vivatex Tbk, PT. Apac Citra Centerex Tbk, PT. Asia Pasific Fibers Tbk, PT. Eratex Djaja Tbk, PT. Suson Textile Manufakturer Tbk, PT. Polychem Indonesia Tbk, PT. Delta Dunia Makmur Tbk, PT. ICTSI Jasa Prima Tbk, PT. Argo Pantes Tbk, PT. Centex (Preferd Stock) Tbk, PT. Ever Shine Textile Industry Tbk, PT. Indorama Synthetic Tbk, PT. Hanson International Tbk, PT. Nusantara Inti Corpora Tbk, PT. Pan Brother Tbk, PT. Panasia Filament Inti Tbk, PT. Panasia Indosyitek Tbk. Dalam operasional perusahaan tersebut agar tetap bertahan dan menghasilkan keuntungan harus dapat menjaga likuditas perusahaan. Likuiditas perusahaan berkaitan dengan pengelolaan modal kerja dan pengelolaan kas. 
Tabel 1. Modal Kerja, Kas dan Hutang Lancar

Pada Perusahaan Tekstil di Bursa Efek IndonesiaTahun 2013-2018

\begin{tabular}{|c|c|c|c|c|}
\hline Thn/No & Nama Perusahaan & $\begin{array}{c}\text { Kas } \\
\text { (Jutaan } \\
\text { Rupiah) } \\
\end{array}$ & $\begin{array}{c}\text { Aset Lancar } \\
\text { (Jutaan } \\
\text { Rupiah) } \\
\end{array}$ & $\begin{array}{c}\text { Hutang Lancar } \\
\text { (Jutaan } \\
\text { Rupiah) } \\
\end{array}$ \\
\hline \multicolumn{5}{|l|}{2013} \\
\hline 1 & PT. Roda Vivatex Tbk & 7.326 & 80.957 & 336.618 \\
\hline 2 & PT. Apac Citra Centerex Tbk & 12.739 & 514.298 & 1.071 .645 \\
\hline 3 & PT. Asia Pasific Fibers Tbk & 5.101 & 235.768 & 1.131 .770 \\
\hline 4 & PT. Eratex Djaja Tbk & 263.460 & 18.105 .441 & 17.972 .500 \\
\hline 5 & PT. Suson Textile Manufakturer Tbk & 1.221 & 298.712 & 201.521 \\
\hline 6 & PT. Polychem Indonesia Tbk & 24.185 & 242.818 & 92.136 \\
\hline 7 & PT. Delta Dunia Makmur Tbk & 215.270 & 421.980 & 300.006 \\
\hline 8 & PT. ICTSI Jasa Prima Tbk & 327.744 & 1.669 .140 & 61.603 .214 \\
\hline \multicolumn{5}{|l|}{2014} \\
\hline 1 & PT. Roda Vivatex Tbk & 84.891 & 183.881 & 203.600 \\
\hline 2 & PT. Apac Citra Centerex Tbk & 20.807 & 581.717 & 1.368 .815 \\
\hline 3 & PT. Asia Pasific Fibers Tbk & 6.184 & 177.420 & 1.126 .846 \\
\hline 4 & PT. Eratex Djaja Tbk & 245.047 & 19.764 .834 & 19.707.005 \\
\hline 5 & PT. Suson Textile Manufakturer Tbk & 1.446 & 398.785 & 299.380 \\
\hline 6 & PT. Polychem Indonesia Tbk & 28.437 & 171.561 & 67.254 \\
\hline 7 & PT. Delta Dunia Makmur Tbk & 75.094 & 301.905 & 127.104 \\
\hline 8 & PT. ICTSI Jasa Prima Tbk & 1.522 .917 & 4.262 .173 & 63.267 .204 \\
\hline \multicolumn{5}{|l|}{2015} \\
\hline 1 & PT. Roda Vivatex Tbk & 298.959 & 393.063 & 190.880 \\
\hline 2 & PT. Apac Citra Centerex Tbk & 5.296 & 493.634 & 1.429 .422 \\
\hline 3 & PT. Asia Pasific Fibers Tbk & 2.657 & 143.251 & 1.101 .821 \\
\hline 4 & PT. Eratex Djaja Tbk & 3.459 .153 & 26.716 .146 & 21.234 .332 \\
\hline 5 & PT. Suson Textile Manufakturer Tbk & 1.748 & 377.298 & 298.508 \\
\hline 6 & PT. Polychem Indonesia Tbk & 30.853 & 151.004 & 59.097 \\
\hline 7 & PT. Delta Dunia Makmur Tbk & 70.617 & 307.841 & 102.527 \\
\hline 8 & PT. ICTSI Jasa Prima Tbk & 361.743 & 2.264 .745 & 61.593 .976 \\
\hline \multicolumn{5}{|l|}{2016} \\
\hline 1 & PT. Roda Vivatex Tbk & 459.932 & 568.220 & 174.693 \\
\hline 2 & PT. Apac Citra Centerex Tbk & 6.300 & 360.309 & 854.929 \\
\hline 3 & PT. Asia Pasific Fibers Tbk & 3.468 & 118.020 & 1.108 .697 \\
\hline 4 & PT. Eratex Djaja Tbk & 3.498 .245 & 21.464.176 & 16.919 .686 \\
\hline 5 & PT. Suson Textile Manufakturer Tbk & 2.420 & 351.706 & 277.524 \\
\hline 6 & PT. Polychem Indonesia Tbk & 20.157 & 132.444 & 71.253 \\
\hline 7 & PT. Delta Dunia Makmur Tbk & 66.935 & 299.288 & 219.305 \\
\hline 8 & PT. ICTSI Jasa Prima Tbk & 886.814 & 4.427 .061 & 61.002 .085 \\
\hline \multicolumn{5}{|l|}{2017} \\
\hline 1 & PT. Roda Vivatex Tbk & 496.200 & 551.269 & 119.405 \\
\hline 2 & PT. Apac Citra Centerex Tbk & 17.551 & 764.428 & 1.643 .507 \\
\hline
\end{tabular}




\begin{tabular}{clrrr}
3 & PT. Asia Pasific Fibers Tbk & 6.240 & 124.065 & 1.111 .724 \\
4 & PT. Eratex Djaja Tbk & 1.645 .054 & 28.014 .261 & 26.955 .857 \\
5 & PT. Suson Textile Manufakturer Tbk & 2.383 & 311.547 & 182.421 \\
6 & PT. Polychem Indonesia Tbk & 27.434 & 149.564 & 69.487 \\
7 & PT. Delta Dunia Makmur Tbk & 67.502 & 352.913 & 218.393 \\
8 & PT. ICTSI Jasa Prima Tbk & 2.107 .064 & 5.998 .669 & 59.562 .450 \\
\hline 2018 & & & & \\
\hline 1 & PT. Roda Vivatex Tbk & 486.114 & 542.644 & 120.721 \\
2 & PT. Apac Citra Centerex Tbk & 16.439 & 714.140 & 1.885 .506 \\
3 & PT. Asia Pasific Fibers Tbk & 4.897 & 133.845 & 1.100 .156 \\
4 & PT. Eratex Djaja Tbk & 863.429 & 30.149 .095 & 29.906 .222 \\
5 & PT. Suson Textile Manufakturer Tbk & 3.324 & 294.172 & 131.917 \\
6 & PT. Polychem Indonesia Tbk & 14.090 & 124.180 & 26.463 \\
7 & PT. Delta Dunia Makmur Tbk & 66.606 & 441.719 & 278.812 \\
8 & PT. ICTSI Jasa Prima Tbk & 1.115 .321 & 6.246 .256 & 58.356 .967 \\
\hline
\end{tabular}

Sumber: Bursa Efek Indonesia, 2018

Pengelolaan modal kerja yang baik akan lebih memperlancar aktivitas perusahaan dalam meningkatkan usaha untuk mencapai keuntungan yang diharapkan. Likuiditas sangat diperlukan oleh sebuah perusahaan sebagai jaminan pemenuhan seluruh kewajiban jangka pendeknya. Pengeloalan modal kerja atau aktiva lancar secara efektif dan efisien sangatlah penting bagi perusahaan, agar dapat mempertahankan likuiditasnya yang sangat berperan dalam menentukan seberapa besar modal kerja yang akan digunakan perusahaan untuk mencapai keuntungan yang diharapkan oleh perusahaan. Berikut dapat diketahui mengenai jumlah modal kerja (aktiva lancar), kas dan hutang lancar dari 18 perusahaan tekstil di Bursa Efek Indonesia hanya 8 perusahaan yang dapat digunakan menjadi sampel penelitian dengan laporan keuangan dari tahun 2013-2018.

Berdasarkan tabel 1 tersebut diketahui bahwa modal kerja atau aktiva lancar pada 8 perusahaan mengalami fluktuasi dan demikian pada jumlah kas serta hutang lancar dari tahun 2013 sampai dengan tahun 2018. Seperti pada perusaahaan PT. Roda Vivatex Tbk jumlah modal kerja atau aktiva lancar dari tahun 2013 sampai tahun 2016 mengalami peningkatan akan tetapi pada tahun 2017 mengalami penurunan. Kemudian untuk kas setiap tahunnya mengalami peningkatan sedangkan untuk hutang lancar setiap tahunnya mengalami penurunan.

Tujuan dari penelitian ini yang ingin dicapai yaitu: 1) Untuk mengetahui pengaruh modal kerja dan perputaran kas secara parsial terhadap tingkat likuiditas (rasio lancar) pada perusahaan tekstil di BEI dan 2) Untuk mengetahui pengaruh modal kerja dan perputaran kas secara simultan terhadap tingkat likuiditas (rasio lancar) pada perusahaan tekstil di BEI.

\section{TINJAUAN PUSTAKA \\ Modal Kerja}

Menurut Fahmi (2012), modal kerja adalah investasi sebuah perusahaan pada aktiva-aktva jangka pendek-kas, persediaan dan piutang. Modal kerja merupakan suatau ukuran dari likuiditas perusahaan. Kamaluddin (2011:109) menyatakan bahwa modal kerja bagi suatu perusahaan adalah sebagai senjata operasional sehari-hari. Apabila senjata tersebut tidak dapat dikendalikan dengan baik, maka akan berdampak aktivitas perusahaan untuk menjalankan operasi perusahaan seperti untuk pembayaran gaji atau upah tenaga kerja, pembelian bahan baku, perawatan mesin dan sebagainya.

Riyanto (2010) menyatakan terdapat tiga konsep mendefenisikan modal kerja, yaitu:

1. Konsep kuantitatif

Konsep ini adalah keseluruhan dari jumlah aktiva lancar. Modal kerja dalam konsep ini sering disebut modal kerja brutto (gros working capital)

2. Konsep kualitatif 
Konsep ini adalah sebagian dari aktiva lancar yang benar-benar dapat digunakan untuk membiayai operasi perusahaan tanpa mengganggu likuiditasnya, yaitu yang merupakan kelebihan aktiva lancar diatas utang lancarnya. Modal kerja dalam pengertian ini sering disebut modal kerja netto (net working capital)

3. Konsep fungsional

Konsep ini mendasarkan pada fungsi dari dana dalam menghasilkan pendapatan (income). Setiap dana yang dikerjakan atau digunakan dalam perusahaan adalah dimaksudkan untuk menghasilkan pendapatan. Ada sebagian dana yang digunakan dalam suatu periode tersebut (current income). dan ada sebagian dana lain yang juga digunakan selama periode tersebut tetapi tidak seluruhnya digunakan untuk menghasilkan "current income".

Harjito dan Martono (2011) mengemukakan konsep modal kerja, yaitu:

1. Konsep kuantitatif

Modal kerja menurut konsep kuantitatif adalah jumlah keseluruhan aktiva lancar yang disebut juga modal kerja bruto (gross working capital). Umumnya elemen-elemen dari modal kerja kuantitatif meliputi kas, surat-surat berharga (sekuritas), piutang dan persediaan.

2. Kosep kualitatif

Pada konsep ini modal kerja dihubungkan dengan besarnya hutang lancar atau hutang yang segera harus dilunasi. Sebagian aktiva lancar dipergunakan untuk melunasi hutang lancar seperti hutang dagang, hutang wesel, hutang pajak, dan sebagian lagi benar-benar dipergunakan untuk membelanjai kegiatan operasional perusahaan.

3. Konsep fungsional

Konsep fungsional mendasarkan pada fungsi dana yang digunakan untuk memperoleh pendapatan. Setiap dana yang dialokasikan pada berbagai aktiva dimaksudkan untuk memperoleh pendapatan (income), baik pendapatan saat ini (current income) maupun pendapatan masa yang akan datang (future income).

Alma (2012) menyatakan pada umumnya mengenal dua sumber permodalan, yaitu:
1. Permodalan sendiri $=$ kekayaan sendiri $=$ sumber intern. Sumber ini berasal dari dalam perusahaan, misalnya penjualan saham, simpanan anggota pada usaha koperasi, cadangan. Kekayaan ini mempunyai ciri yaitu terikat secara permanen dalam perusahaan.

2. Permodalan asing=kekayaan asing=sumber ekstern. Sumber ini berasal dari pihak luar perusahaan yaitu berupa pinjaman jangka panjang atau jangka pendek. Pinjaman jangka pendek yaitu pinjaman yang jangka waktu maksimumnya satu tahun. Sedangkan pinjaman yang jangka waktunya lebih dari satu tahun, disebut kredit jangka panjang seperti obligasi, hipotek dan sebagainya, ciri dari kekayaan asing ini ialah tidak terikat secara permanen atau hanya terikat sementara, yang sewaktu-waktu akan dikembalikan lagi kepada yang meminjamkan.

Andreas (2011:2) menyatakan bahwa terdapat beberapa sumber modal yang terdiri dari:

1. Modal sendiri (ownership)

Modal sendiri dapat berasal dari tabungan pribadi, teman-teman, dan saudara bahkan rekan, sumber dana yang paling baik untuk memulai suatu bisnis adalah berasal dari tabungan pribadi.

2. Modal hutang (debt capital)

Anda dapat memulai bisnis anda dengan modal pinjaman yang mungkin dapat anda peroleh dari sumber-sumber berikut ini:
a. Bank-bank komersil
b. Pemasok (vendors)
c. Anjak piutang (factors)
d. Lain-lain (perusahaan asuransi, perusahaan pembiayaan, pemerintah)

\section{Kas}

Harahap (2010) menyatakan kas adalah uang dan surat berharga lainnya yang dapat diuangkan setiap saat serta surat berharga lainnya yang sangat lancar yang memenuhi syarat sebagai berikut:

1. Setiap saat dapat ditukar menjadi kas.

2. Tanggal jatuh temponya sangat dekat.

3. Kecil resiko perubahan nilai yang disebabkan perubahan tingkat harga.

Menurut Ikatan Akuntansi Indonesia (2013), kas adalah terdiri dari saldo kas (cash on hand) dan rekening giro. Setara kas (cash 
equivalent) adalah investasi yang sifatnya sangat liquid, berjangka pendek dan dengan cepat dapat dijadikan sebagai kas dalam jumlah tertentu tanpa menghadapai risiko perubahan nilai yang signifikan.

Ikatan Akuntansi Indonesia (2013) menyebutkan bahwa sumber penerimaan kas terdiri dari:

1. Aktivitas operasi

Aktivitas operasi adalah aktivitas penghasil utama pendapatan entitas dan aktivitas lain yang bukan merupakan aktivitas investasi dan aktivitas pendanaan. Kas tersebut pada umumnya berasal dari transaksi dan peristiwa lain yang mempengaruhi penetapan laba atau rugi neto. Beberapa contoh arus kas dari aktivitas operasi adalah:

a. Penerimaan kas dari penjualan barang dan pemberian jasa

b. Penerimaan kas dari royalty, fees, komisi, dan pendapatan lain

c. Pembayaran kas kepada pemasok barang dan jasa

d. Pembayaran kas kepada dan untuk kepentingan karyawan

e. Penerimaan dan pembayaran kas oleh entitas asuransi sehubungan dengan premi, klaim, anuitas, dan manfaat polis lain

f. Pembayaran kas atau penerimaan kembali (restitusi) pajak penghasilan kecuali jika dapat diidentifikasikan secara khusus sebagai bagian dari aktivitas pendanaan dan investasi; dan

g. Penerimaan dan pembayaran kas dari kontrak yang dimiliki untuk tujuan diperdagangkan atau diperjualbelikan (dealing).

2. Aktivitas Investasi

Aktivitas investasi adalah perolehan dan pelepasan aset jangka panjang serta investasi lain yang tidak termasuk setara kas. Beberapa contoh arus kas yang berasal dari aktivitas investasi adalah:

a. Pembayaran kas untuk membeli asset tetap, tidak berwujud, dan aset jangka panjang lain, termasuk biaya pengembangan yang dikapitalisasi dan aset tetap yang dibangun sendiri.

b. Penerimaan kas dari penjualan aset tetap, aset tidak berwujud dan aset jangka panjang lain.

c. Pembayaran kas untuk membeli instrumen utang atau instrumen ekuitas entitas lain dan kepemilikan dalam ventura bersama (selain pembayaran kas untuk instrumen yang dianggap setara kas atau instrumen yang dimiliki untuk diperdagangkan atau dijualbelikan)

d. Penerimaan kas dari penjualan instrumen utang dan instrumen ekuitas entitas lain dan kepemilikan ventura bersama (selain penerimaan kas dari instrumen yang dianggap setara kas atau instrumen yang dimiliki untuk diperdagangkan atau diperjualbelikan).

e. Uang muka dan pinjaman yang diberikan kepada pihak lain (selain uang muka dan kredit yang diberikan oleh lembaga keuangan).

f. Penerimaan kas dari pelunasan uang muka dan pinjaman yang diberikan kepada pihak lain (selain uang muka dan kredit yang diberikan oleh lembaga keuangan).

g. Pembayaran kas sehubungan dengan kontrak, kecuali jika kontrak tersebut dimiliki untuk tujuan perdagangkan atau diperjualbelikan, atau jika pembayaran tersebut diklasifikasikan sebagai aktivitas pendanaan; dan

3. Aktivitas Pendanaan

Aktivitas pendanaan adalah aktivitas pendanaan adalah aktivitas yang mengakibatkan perubahan dalam jumlah serta komposisi kontribusi modal dan pinjaman entitas. Beberapa contoh arus kas yang berasal dari aktivitas pendanaan adalah:

a. Penerimaan kas dari penerbitan saham atau instrument modal lain.

b. Pembayaran kas kepada pemilik untuk menarik atau menebus saham entitas.

c. Penerimaan kas dari penerbitan obligasi, pinjaman, wesel, hipotek, dan pinjaman jangka pendek dan jangka panjang lain

d. Pelunasan pinjaman

e. Pembayaran kas oleh lessee untuk mengurangi saldo liabilitas yang berkaitan dengan sewa pembiayaan

\section{Perputaran Kas}

Menurut Riyanto (2010), perputaran kas adalah perbandingan antara penjualan dengan jumlah kas rata-rata. Tingkat 
perputaran kas merupakan ukuran efisiensi penggunaan kas yang dilakukan oleh perusahaan. Karena tingkat perputaran kas menggambarkan kecepatan arus kas kembalinya kas yang telah ditanamkan di dalam modal kerja. Dalam mengukur tingkat perputaran kas, sumber masuknya kas yang telah tertanam dalam modal kerja adalah berasal dari aktivitas operasional perusahaan. Perputaran kas dalam satu periode dapat dihitung dengan rumus (Riyanto, 2010):

$$
\text { Perputaran kas }=\frac{\text { Penjualan bersih }}{\text { rata }- \text { rata kas dan setara kas }}
$$

$$
\text { Rasio lancar }=\frac{\text { aktiva lancar }}{\text { hutang lancar }}
$$

2. Rasio cepat

Besarnya aktiva lancar terhadap hutang lancar. Hal ini dapat diukur dengan rasio ini.

Rasio cepat $=\frac{\text { aktiva lancar }- \text { persediaan }}{\text { hutang lancar }}$

3. Rasio kas

Kas harus tersedia untuk membayar tagihan-tagihan yang jatuh tempo dalam hitungan minggu ataupun bulan. Pengukuran terhadap kecukupan kas dapat Rata - rata kas dan setara kas $=\frac{\text { Kas awal tahun }+ \text { kas dikknkan dengan menggunakan rasio kas }}{2 \text { terhadap kewajiban lancar. Rasio ini }}$

Semakin tinggi tingkat perputaran kas berarti semakin cepat kembalinya kas masuk pada perusahaan. Dengan demikian kas akan dapat dipergunakan kembali untuk membiayai kegiatan operasional sehingga tidak mengganggu kondisi keuangan perusahaan. Menurut Sartono (2010), perputaran kas merupakan perbandingan jumlah penjualan atau sales dengan rata-rata kas dalam satu periode. Makin tinggi perputaran kas makin baik. Karena ini berarti makin tinggi efisiensi penggunaan kasnya. Tetapi perputaran kas yang berlebih-lebihan tingginya dapat berarti bahwa jumlah kas yang tersedia adalah terlalu kecil untuk volume penjualan tersebut.

\section{Pengertian Likuiditas}

Syamsudin (2014) menyatakan bahwa rasio likuiditas merupakan suatu perusahaan yang ingin mempertahankan kelangsungan kegiatan usahanya harus memiliki kemampuan untuk melunasi kewajiban-kewajiban finansial yang segera dilunasi. Sedangkan menurut Sitio dan Tamba (2011), likuiditas adalah alat untuk mengetahui kemampuan perusahaan untuk memenuhi kewajiban-kewajiban finansialnya dalam jangka pendek. Sedangkan menurut Hanafi dan Halim (2014), likuiditas adalah rasio kemampuan likuiditas jangka pendek perusahaan dengan melihat besarnya aktiva lancar relatif terhadap utang lancarnya.

Sawir (2010) menyatakan rasio likuiditas dapat diukur dengan:

\section{Rasio lancar}

Rasio ini mengukur kemampuan sesungguhnya untuk memenuhi utangutang tepat pada waktunya. Dengan rumus
2 mengukur kemampuan sesungguhnya untuk memenuhi utang-utang tepat pada waktunya.

$$
\text { Rasio kas }=\frac{\text { kas }}{\text { hutang lancar }}
$$

Pada penelitian ini likuiditas menggunakan rasio lancar dikarenakan rasio ini langsung menggunakan seluruh aktiva lancar pada perusahaan yang dibandingkan dengan seluruh hutang lancar. Seperti diketahui bahwa aktiva lancar merupakan modal kerja perusahaan atau harta yang likuid dan dapat langsung digunakan dalam operasional perusahaan. Kemudian didukung dengan penelitian sebelumnya yang dilakukan Iradawati (2011) untuk variabel likuiditas menggunakan rasio lancar (current ratio).

\section{METODE PENELITIAN \\ Jenis dan Sumber Data}

Jenis dan sumber data yang digunakan dalam penelitian ini yaitu:

1 .

Data kualitatif adalah data bukan angka namun diangkakan (Sujarweni, 2015). Data kualitatif pada penelitian ini berupa teori-teori dan gambaran umum Perusahaan Tekstil.

2.

Data Kuantitatif
Data Kuantitatif adalah data yang
berbentuk angka (Sujarweni, 2015).
Data ini terbagi menjadi data yang
diperoleh dengan cara angka dari
laporan keuangan masing-masing
perusahaan tekstil di BEI tahun 2013-
2017.

Sumber data yang digunakan dalam penelitian ini yaitu data sekunder. Data 
Sekunder adalah data yang didapat dari catatan, buku dan majalah berupa laporan keuangan publikasi perusahaan, laporan pemerintah, artikel, buku-buku sebagai teori, majalah dan lain sebagainya (Sujarweni, 2015:89). Data sekunder diperoleh dari buku, jurnal, artikel dan laporan keuangan perusahaan tekstil yang ada kaitannya dengan penelitian ini.

\section{Populasi dan Sampel}

Menurut Sugiyono (2011), populasi adalah wilayah generalisasi yang terdiri atas obyek/subyek yang mempunyai kualitas dan karakteristik tertentu yang ditetapkan peneliti untuk dipelajari dan kemudian ditarik kesimpulannya. Sampel adalah bagian dari jumlah dan karakteristik yang dimiliki populasi (Sugiyono, 2011). Populasi pada penelitian ini perusahaan tekstil yang terdaftar di Bursa Efek Indonesia sebanyak 18 perusahaan. Tehnik sampling menggunakan non probability sampling yaitu tehnik pengambilan sampel yang tidak memberi peluang/kesempatan sama bagi setiap unsur atau anggota populasi untuk dipilih menjadi sampel (Sujarweni, 2015). Kemudian pengambilan sampel menggunakan metode purposive sampling yaitu tehnik penentuan sampel dengan pertimbangan atau kriteriakriteria tertentu (Sujarweni, 2015), yang menjadi pertimbangan adalah:

1. Perusahaan tekstil yang terdaftar di Bursa Efek Indonesia.

2. Perusahaan yang menerbitkan laporan keuangan berturut-turut dari tahun 20132018.

3. Tersedia data untuk menghitung modal kerja, perputaran kas dan rasio likuiditas.

Dari 18 perusahaan terdapat 8 perusahaan dengan laporan keuangan berupa neraca dari tahun 2013-2018. Kedelapan perusahaan tersebut adalah:

1. PT. Roda Vivatex Tbk

2. PT. Apac Citra Centerex Tbk

3. PT. Asia Pasific Fibers Tbk

4. PT. Eratex Djaja Tbk

5. PT. Suson Textile Manufacture Tbk

6. PT. Polychem Indonesia Tbk

7. PT. Delta Dunia Makmur Tbk

8. PT. ICTSI Jasa Prima Tbk

\section{Metode Pengumpulan Data}

Teknik pengumpulan data yang digunakan dalam penelitian ini yaitu:

1. Studi dokumentasi yaitu pengumpulan data dengan mempelajari jurnal ilmiah dan buku serta penelusuran internet berkaitan dengan masalah yang diteliti (Fachrudin dan Meliza, 2014). Dokumen pada penelitian ini adalah laporan keuangan tahun 2013-2017 dari 8 perusahaan tekstil di Bursa Efek Indonesia.

2. Kajian pustaka adalah seperangkat konstruk atau konsef, defines dan proposisi yang berfungsi untuk melihat fenomena secara sistematik, melalui spesifikasi hubungan antara variabel, sehingga dapat berguna untuk menjelaskan dan meramalkan fenomena (Sujarweni, 2015). Kajian pustaka dilakukan dengan membaca buku-buku, jurnal dan artikel yang berkaitan dengan penelitian.

\section{Metode Analisis Data}

Untuk menganalisis pengaruh modal kerja dan perputaran kas terhadap tingkat likuiditas menggunakan analisis regresi linier berganda dengan rumus sebagai berikut (Sugiyono, 2011):

$\mathrm{Y}=\mathrm{a}+\mathrm{b}_{1} \mathrm{X}_{1}+\mathrm{b}_{2} \mathrm{X}_{2}+\ldots \mathrm{b}_{\mathrm{n}} \mathrm{X}_{\mathrm{n}}$

Keterangan:

$\mathrm{Y}=$ Variabel dependen

$\mathrm{b}_{1}, \mathrm{~b}_{2}, \mathrm{~b}_{\mathrm{n}} \quad=$ Koefisien Regresi

$\mathrm{X}_{1}, \mathrm{X}_{2}, \mathrm{X}_{\mathrm{n}} \quad=$ Variabel independen

Kemudian penulis memodifikasi persamaan di atas sebagai berikut:

$\mathrm{Y}=\mathrm{a}+\mathrm{b}_{1} \mathrm{X}_{1}+\mathrm{b}_{2} \mathrm{X}_{2}$

Keterangan :

$\mathrm{Y}=$ Rasio lancar

a $\quad=$ Kostanta

$\mathrm{b}_{1, \mathrm{~b}_{2}} \quad=$ Koefisien Regresi

$\mathrm{X}_{1} \quad=$ modal kerja

$\mathrm{X}_{2} \quad=$ perputaran kas

Untuk menguji hipotesis, maka dgunakan pengujian sebagai berikut:

1. Uji t (uji parsial)

Uji t dgunakan untuk menguji signifikansi pengaruh variabel independen secara parsial terhadap variabel dependen (Ghozali, 2016:99). Hipotesis yang digunakan yaitu:

$\mathrm{H}_{\mathrm{o}}$ : Variabel-variabel independen yaitu modal kerja dan perputaran kas secara parsial berpengaruh tidak signifikan terhadap variabel 
dependennya yaitu rasio lancar.

$\mathrm{H}_{\mathrm{a}}$ : Variabel-variabel independen yaitu modal kerja dan perputaran kas secara parsial berpengaruh signifikan terhadap variabel dependennya yaitu rasio lancar.

Kriteria pengambilan keputusan sebagai berikut:

a. $\mathrm{H}_{\mathrm{o}}$ diterima jika $\mathrm{t}_{\mathrm{sig}}>\alpha=5 \%$

b. $\mathrm{H}_{\mathrm{a}}$ diterima jika $\mathrm{t}_{\mathrm{sig}}<\alpha=5 \%$

2. Uji F (uji simultan)

Uji $F$ digunakan untuk menguji signifikansi pengaruh variabel independen secara simultan terhadap variabel dependen (Ghozali, 2016:99). Hipotesis yang digunakan, yaitu:

$\mathrm{H}_{\mathrm{o}}$ : Variabel-variabel independen modal kerja dan perputaran kas secara simultan berpengaruh tidak signifikan terhadap variabel dependennya yaitu rasio lancar.

$\mathrm{H}_{\mathrm{a}}$ : Variabel-variabel independen yaitu modal kerja dan perputaran kas secara simultan berpengaruh signifikan terhadap variabel dependennya yaitu rasio lancar.

Kriteria pengambilan keputusan adalah sebagai berikut:

a. $\mathrm{H}_{\mathrm{o}}$ diterima jika $\mathrm{F}_{\mathrm{sig}}>\alpha=5 \%$

b. $\mathrm{H}_{\mathrm{a}}$ diterima jika $\mathrm{F}_{\text {sig }}<\alpha=5 \%$

3. $\quad \mathrm{Uji}^{2}$ (Koefisien Determinasi)

Uji koefisien determinasi digunakan untuk mengetahui seberapa besar variasi dan variabel independen mempengaruhi variabel dependen. Angka koefisien determinasi berkisar antara 0 (nol) sampai 1 (satu). Angka $\mathrm{R}^{2}$ yang semakin

\section{HASIL DAN PEMBAHASAN}

Pengaruh modal kerja dan perputaran kas terhadap likuiditas (rasio lancar) diketahui dari hasil analisis data dengan menggunakan persamaan regresi linier berganda.
Berdasarkan tabel 2 dapat dibuat persamaan regresi linier berganda sebagai berikut: dijelaskan:

$\mathrm{Y}=511,159-61,824 \mathrm{X}_{1}-0,002 \mathrm{X}_{2}$

Berdasarkan persamaan tersebut dapat

1. Konstanta sebesar 511,159 dapat dinyatakan bahwa jika variabel bebas modal kerja dan perputaran kas dianggap tetap, maka perubahan variabel terikat likuiditas (rasio lancar) adalah sebesar 511,159 .

2. Koefisien regresi modal kerja menunjukkan bahwa nilai koefisien sebesar $-61,824$ dan dapat dinyatakan bahwa modal kerja berpengaruh negatif terhadap likuiditas (rasio lancar), apabila modal kerja meningkat satu satuan maka akan menurunkan likuiditas pada perusahaan tekstil yang terdaftar di Bursa Efek Indonesia sebesar 61,824 dengan asumsi variabel perputaran kas bernilai tetap.

3. Koefisien regresi perputaran kas menunjukkan bahwa nilai koefisien sebesar -0,002 dan dapat dinyatakan bahwa perputaran kas berpengaruh negatif terhadap likuiditas (rasio lancar), apabila perputaran kas meningkat satu satuan maka akan menurunkan likuiditas pada perusahaan tekstil yang terdaftar di Bursa Efek Indonesia sebesar 0,002 dengan asumsi variabel modal kerja bernilai tetap.

Tabel 3 memperlihatkan nilai koefisien determinasi $\left(\mathrm{R}^{2}\right)$ berupa $R$ Square sebesar 0,182 . Nilai 0,182 atau $18,2 \%$ variabel modal kerja dan perputaran kas mempengaruhi tingkat likuiditas (rasio lancar) pada perusahaan tekstil yang terdaftar di Bursa Efek Indonesia. Kemudian sebesar 81,8\% tingkat likuiditas dipengaruhi variabel lain yang tidak diteliti pada penelitian ini seperti variabel perputaran piutang dan persediaan.

Tabel 2. Coefficients

\begin{tabular}{|c|c|c|c|c|c|}
\hline \multirow[t]{2}{*}{ Model } & \multicolumn{2}{|c|}{$\begin{array}{c}\text { Unstandardized } \\
\text { Coefficients }\end{array}$} & $\begin{array}{c}\text { Standardized } \\
\text { Coefficients }\end{array}$ & \multirow[t]{2}{*}{$\mathrm{t}$} & \multirow[t]{2}{*}{ Sig. } \\
\hline & $\mathrm{B}$ & Std. Error & Beta & & \\
\hline (Constant) & 511,159 & 143,969 & & 3,550 & ,001 \\
\hline Modal Kerja & $-61,824$ & 24,321 &,- 353 & $-2,542$ &, 015 \\
\hline
\end{tabular}


a. Dependent Variable: Likuiditas

Sumber: hasil penelitian, diolah (2019)

Tabel 3. Model Summary

\begin{tabular}{|l|r|r|r|r|}
\hline Model & \multicolumn{1}{|c|}{ R } & R Square & Adjusted R Square & $\begin{array}{c}\text { Std. Error of the } \\
\text { Estimate }\end{array}$ \\
\hline 1 &, $427^{\mathrm{a}}$ &, 182 &, 146 & 119,04450 \\
\hline
\end{tabular}

a. Predictors: (Constant), Perputaran Kas, Modal Kerja

Sumber: hasil penelitian, diolah (2019)

Tabel 4. ANOVA

\begin{tabular}{|rl|r|r|r|r|r|}
\hline Model & & Sum of Squares & df & Mean Square & F & Sig. \\
\hline \multirow{2}{*}{1} & Regression & 142233,061 & 2 & 71116,530 & 5,018 &, $011^{\mathrm{b}}$ \\
& Residual & 637721,718 & 45 & 14171,594 & & \\
& Total & 779954,778 & 47 & & & \\
\hline
\end{tabular}

a. Dependent Variable: Likuiditas

b. Predictors: (Constant), Perputaran Kas, Modal Kerja

Sumber: hasil penelitian, diolah (2019)

\section{Pembuktian Hipotesis}

Hipotesis dalam penelitian ini diuji dengan menggunakan uji t (uji secara parsial dan uji F (uji secara simultan). Pengujian menggunakan nilai $\mathrm{t}$ sig dan $\mathrm{F}$ sig serta tingkat kesalahan sebesar $\alpha 5 \%(0,05)$. Hasil uji $t$ dapat diketahui sebagai berikut.

1. Hasil Uji t

Uji t dilakukan denan membandingkan antara nilai t sig pada tabel 2 dengan nilai $\alpha 5 \%(0,05)$, hasil uji sebagai berikut:

a. Modal kerja diperoleh nilai $\mathrm{t} \operatorname{sig}<\alpha$ $5 \%$ atau $(0,015<0,05)$ dapat dinyatakan bahwa modal kerja berpengaruh signifikan terhadap tingkat likuiditas (rasio lancar) pada perusahaan tekstil pada perusahaan Bursa Efek Indonesia sehingga hipotesis dapat diterima. Modal kerja sangat penting dalam sebuah perusahaan, karena dengan modal kerjalah sebuah perusahaan dapat beroperasi dan menjadi pengukur tingkat likuditas bagi perusahaan, hal ini sesuai dengan pendapat Fahmi (2012) bahwa modal kerja adalah investasi sebuah perusahaan pada aktiva-aktiva jangka pendek kas, persediaan dan piutang serta modal kerja merupakan suatu ukuran dari likuiditas perusaahaan. Hasil penelitian sesuai dengan penelitian sebelumnya yang dilakukan Rosmawati, Yuliza dan Afriyanto (2015) dimana variabel modal kerja memberikan pengaruh signifikan terhadap likuditas (rasio lancar).

b. Perputaran kas diperoleh nilai $\mathrm{t} \operatorname{sig}<\alpha$ $5 \%$ atau $(0,019<0,05)$ dapat dinyatakan bahwa perputaran kas berpengaruh signifikan terhadap tingkat likuiditas (rasio lancar) pada perusahaan tekstil pada perusahaan Bursa Efek Indonesia sehingga hipotesis penelitian dapat diterima. Perputaran kas memberikan gambaran mengenai aliran kas dalam sebuah perusahaan dimana tingkat perputaran yang cepat akan menggambarkan kas yang digunakan cepat kembali menjadi dan ditanamkan menjadi modal dan hal sangat baik bagi perusahaan. Hal ini sesuai dengan pendapat dari Riyanto (2010), 
semakin tinggi tingkat perputaran kas berarti semakin cepat kembalinya kas masuk pada perusahaan. Dengan demikian kas akan dapat dipergunakan kembali untuk membiayai kegiatan operasional sehingga tidak mengganggu kondisi keuangan perusahaan. Hasil penelitian menunjukkan perputaran kas berpengaruh signifikan terhadap likuiditas (rasio lancar) dan ini sesuai dengan penelitian sebelumnya yang dilakukan Astuti (2014) melakukan penelitian dengan hasil penelitiannya menunjukkan bahwa perputaran kas memberikan pengaruh signifikan terhadap likuditas (rasio lancar).

2. Hasil uji $\mathrm{F}$

Hasil uji $F$ dilakukan dengan membandingkan nilai $\mathrm{F}$ sig pada tabel 4 dengan nilai $\alpha 5 \%$. Hasil uji $F$ diketahui dari nilai $\mathrm{F}$ sig $0,011<\alpha 5 \%(0,05)$ dan berdasarkan hasil ini dapat dinyatakan bahwa modal kerja dan perputaran kas secara simultan berpengaruh signifikan terhadap likuiditas (rasio lancar), sehingga hipotesis dapat diterima. Berdasarkan pendapat Fahmi (2012) bahwa modal kerja adalah investasi sebuah perusahaan pada aktiva-aktiva jangka pendek kas, persediaan dan piutang serta modal kerja merupakan suatu ukuran dari likuiditas perusaahaan dan pendapat Riyanto (2010), semakin tinggi tingkat perputaran kas berarti semakin cepat kembalinya kas masuk pada perusahaan. Dengan demikian kas akan dapat dipergunakan kembali untuk membiayai kegiatan operasional sehingga tidak mengganggu kondisi keuangan perusahaan, maka dapat modal kerja dan perputaran kas dapat memberikan pengaruh signifikan terhadap likuiditas (rasio lancar) serta hasil penelitian tersebut didukung dengan penelitian sebelumnya yang dilakukan oleh Rosmawati, Yuliza dan Afriyanto (2015) dengan hasil bahwa modal kerja berpengaruh signifikan terhadap likuiditas. Kemudian penelitian Rantulalo, Murni dan Tulung (2018) melakukan penelitian dengan hasil penelitian bahwa perputaran kas berpengaruh signifikan terhadap likuiditas.

\section{KESIMPULAN DAN SARAN \\ Kesimpulan}

Kesimpulan dari penelitian yaitu: (1) Berdasarkan hasil persamaan regresi linier berganda diketahui bahwa modal kerja dan perputaran kas memberikan pengaruh negatif terhadap likuiditas (rasio lancar) pada perusahaan tekstil yang terdaftar di Bursa Efek Indonesia tahun 2013-2018. (2) Hasil uji koefisien determinasi $\left(\mathrm{R}^{2}\right)$ diketahui sebesar 18,2\% modal kerja dan perputaran kas memberikan pengaruh terhadap likuiditas (rasio lancar) pada perusahaan tekstil yang terdaftar di Bursa Efek Indonesia dari tahun 2013-2018, (3) Hasil uji t, diketahui bahwa modal kerja berpengaruh signifikan terhadap likuiditas (rasio lancar) pada perusahaan tekstil yang terdaftar di Bursa Efek Indonesia dengan kondisi data dari tahun 2013-2018. Kemudian perputaran kas berpengaruh signifikan terhadap likuiditas (rasio lancar) pada perusahan tekstil yang terdaftar di Bursa Efek Indonesia dari tahun 20132018, (4) Hasil uji F diketahui bahwa secara simultan modal kerja dan perputaran kas berpengaruh signifikan terhadap likuiditas (rasio lancar) pada perusahan tekstil yang terdaftar di Bursa Efek Indonesia dari tahun 2013-2018.

\section{Saran}

Saran-saran yang dapat diberikan, yaitu: (1) Kepada pihak manajemen perusahaan tekstil harus meningkatkan jumlah modal kerja (aktiva lancar) yang jumlahnya harus lebih besar dibandingkan dengan jumlah hutang lancar, karena apabila hutang lancar yang terlalu besar bila dibandingkan dengan modal kerja (aktiva lancar) akan menurunkan tingkat likuiditas. (2) Kepada pihak manajemen perusahan juga harus mengatur tingkat perputaran kas, terlalu tinggi perputaran kas dan tanpa memperhatikan hutang lancar juga akan menurunkan likuiditas (rasio lancar). (3) Kepada investor, sebaiknya memilih perusahaan yang memiliki tingkat paling baik dalam melakukan investasi, (4) Kepada peneliti 
selanjutnya yang ingin meneliti tentang tingkat likuiditas, dapat menambahkan variabel lain seperti perputaran piutang dan persediaan.

\section{REFERENSI}

Alma, Buchari. 2012. Pengantar Bisnis. Bandung: Alfabeta.

Andreas, 2011. Manajemen Keuangan. Bandung: Alfabeta.

Astuti, Eka. 2014. Pengaruh Perputaran Piutang dan Perputaran Kas terhadap Likuiditas. Jurnal Studia. Vol. 11. No.1 Hal 1-16.

Fahmi, Irham. 2012. Pengantar Manajemen Keuangan. Bandung: Alfabeta

Facharuddin. K.A dan Meliza. J. 2014. Metode Penelitian. Medan: USU Press

Harahap, Sofyan Safri. 2010. Analisis Laporan Keuangan. Jakarta: Rajawali Pers.

Harjito, Agus dan Martono. 2011. Manajemen Keuangan. Yogyakarta: Ekonosia

Ikatan Akuntansi Indonesia. 2013. Standar Akuntansi Keuangan. Jakarta: Salemba Empat.

Kamaluddin. 2011. Manajemen Keuangan. Bandung: Mandar Maju.
Rantulalo, Rauna. Murni Sri dan Tulung Joy.E. 2018. Pengaruh Perputaran Kas dan Piutang terhadap Likuiditas pada Perusahaan Finance Institution yang terdaftar di Bursa Efek Indonesia (Periode 2013-2017). Jurnal EMBA. Vol. 6. No. 4. Hal. 2838-2846.

Riyanto, Bambang. 2010. Dasar-dasar Pembelanjaan Perusahaan. Yogyakarta: BPFE-Yogyakarta.

Rosmawati, Irma, Yuliza Arma dan Afriyanto. 2015. Analisis Pengaruh Modal Kerja terhadap Likuiditas pada PT. Indoritel Makmur Internasional Tbk. Jurnal Ekonommi \& Akuntansi, Vol 3. No. 1. Hal. 1-5

Sartono, Agus. 2010. Manajemen Keuangan Teori dan Aplikasi. Yogyakarta: BPFE.

Sugiyono. 2011. Statistik Untuk Penelitian. Bandung: Alfabeta.

Sujarweni, V.W. 2015. Metode Penelitian Bisnis \& Ekonomi. Yogyakarta: Pustaka Baru Press.

Syamsuddin, Lukman. 2014. Manajemen Keuangan Perusahaan. Jakarta: Raja Grafindo Persada

www.idx.co.id. 2018. Laporan Keuangan Perusahaan Tekstil. Diunduh Desember 2018. 